\title{
PENERAPAN METODE GEOLISTRIK KONFIGURASI WENNER - SCHLUMBERGER UNTUK ANALISIS REMBESAN PADA MAINDAM WADUK GRENENG, KABUPATEN BLORA
}

\author{
Dian Chandrasasi ${ }^{1}$, Runi Asmaranto ${ }^{1}$, Ni Made Candra Partarini ${ }^{2}$ \\ ${ }^{1}$ Dosen Jurusan Teknik Pengairan, Fakultas Teknik, Universitas Brawijaya, Malang \\ ${ }^{2}$ Mahasiswa Sarjana Teknik Pengairan, Fakultas Teknik, Universitas Brawijaya, Malang \\ e-mail : labelledian@ub.ac.id
}

\begin{abstract}
ABSTRAK : Bendungan Greneng yang berusia hampir 100 tahun terindikasi terjadi rembesan pada tubuh bendungan yang terlihat dari longsoran pada dinding tumpuan hilir bendungan. Studi ini bertujuan untuk mengetahui rembesan secara visual pada tubuh Bendungan Greneng dan untuk mengetahui posisi pola rembesan di lereng tubuh dan pondasi Bendungan Greneng dengan Geolistrik konfigurasi Wenner-Schlumberger. Secara visual terdapat 6 (enam) spot rembesan dimana, satu spot rembesan diduga sebagai akibat aliran air tanah. Adapun indikasi posisi rembesan tersebut keseluruhannya terletak pada hilir tubuh bendungan. Hasil pengukuran alat Geolistrik konfigurasi Wenner-Schlumberger dengan pengolahan aplikasi RES2DINV diperoleh hasil posisi rembesan yang diwakili oleh nilai resistivitas paling rendah dengan gradasi berwarna biru. Hasil keempat garis kerja dapat diperhatikan bahwa setiap Line menunjukan adanya potensi rembesan yang berbeda-beda namun, dapat diketahui terdapat potensi aliran rembesan pada setiap daerah Main Dam Waduk Greneng yang ditandai dengan adanya resistivitas rendah yang ditandai dengan warna biru.
\end{abstract}

Kata kunci: rembesan, resistivitas, metode geolistrik, konfigurasi Wenner - Schlumberger.

\begin{abstract}
The nearly 100-year-old Greneng dam is indicated by seepage in the main dam visible from landslides on the downstream of the dam wall. This study aims to determine visible seepage in the main dam of Greneng Dam and to find out the position of seepage pattern on the body slope and foundation of Greneng Dam by Electrical Geology configuration of WennerSchlumberger. Visually there are 6 (six) spot seepage where, one spot of seepage is suspected as a result of groundwater flow. The indication of the seepage position is entirely located on the downstream of the main dam. The measurement result by Electrical Geology configuration of Wenner-Schlumberger with the processing of RES2DINV application obtained the result of seepage position which is represented by the lowest resistivity value with blue gradation. The results of the four work lines can be observed that each line shows the potential for different seepage, however, it can be seen that there is a potential flow of seepage in each area of Main Dam Greneng Dam which is characterized by low resistivity marked with blue color.
\end{abstract}

Keywords: seepage, resistivity, electrical geology method, configuration of Wenner-Schlumberger

Bendungan Greneng yang sudah berusia hampir 100 tahun yang dibangun pada tahun 1919, juga terindikasi adanya peningkatan rembesan yang disebabkan pelapukan pada pondasi batuan limestone. Selain itu ada gejala rembesan pada tubuh bendungan yang terlihat dari longsoran pada dinding tumpuan hilir bendungan. Untuk itu perlu dilakukan penelitian terkait letak titik kebocoran yang diakibatkan oleh menurunkan nilai permeabilitas tanah pada pondasi dan tubuh bendungan.
Berdasarkan permasalahan tersebut di atas maka, sangat diperlukan kajian dan analisis rembesan khususnya yang terjadi di tubuh dan pondasi Bendungan Greneng yang mengalami gejala peningkatan debit rembesan di lahan bagian hilir bendungan. Analisa mengenai rembesan ini diperlukan untuk menjamin keamanan bendungan dari kemungkinan kegagalan konstruksi akibat erosi buluh akibat erosi yang tidak terkendali.

Salah satu alternatif yang digunakan untuk menangani permasalahan ini yaitu dengan menggunakan metode geoelektrikal. 
Metode ini dipandang lebih efektif dan efisien dengan hasil yang akurat untuk mengetahui aliran rembesan pada tubuh bendungan. Adapun penerapan metode geolistrik menggunakan konfigurasi Wenner Schlumberger. Konfigurasi ini dianggap sesuai dengan kondisi struktur tubuh bendungan guna mengetahui aliran rembesan yang terjadi.

Tujuan dilakukannya studi ini adalah untuk mengetahui rembesan secara visual pada tubuh Bendungan Greneng dan untuk mengetahui posisi pola rembesan di lereng tubuh dan pondasi bendungan di Indonesia khususnya Bendungan Greneng dengan Geolistrik konfigurasi Wenner-Schlumberger.

Dalam merencanakan sebuah
bendungan perlu diperhatikan stabilitasnya terhadap bahaya longsoran, erosi lereng dan kehilangan air akibat rembesan yang melalui tubuh bendungan. Baik tubuh bendungan maupun pondasinya diharuskan mampu mempertahankan diri terhadap gaya - gaya yang di timbulkan oleh adanya air filtrasi yang mengalir melalui celah - celah antara butiran - butiran tanah pembentuk tubuh bendungan dan pondasi tersebut. (Hardiyatmo, 2007a: 255).

Hukum Darcy dapat digunakan untuk menghitung debit rembesan yang melalui struktur bendungan. Dalam merencanakan sebuah bendungan, perlu diperhatikan stabilitasya terhadap bahaya longsoran, erosi lereng dan kehilangan air akibat rembesan yang melalui tubuh bendungan. Beberapa cara diberikan untuk menentukan besarnya rembesan yang melewati bendungan yang dibangun dari tanah homogennya. Berikut ini disajikan beberapa cara untuk menentukan debit rembesan.

Darcy (1856), mengusulkan hubungan antara kecepatan dan gradient hidrolik sebagai berikut :

$v=k \times \frac{\Delta h}{l}$

dengan :

$V \quad=$ kecepatan air $(\mathrm{cm} / \mathrm{det})$

$\Delta h=$ beda tinggi elevasi $(\mathrm{cm})$

$\mathrm{L}=$ jarak A dan B $(\mathrm{cm})$

$k=$ koefisien Permeabilitas $(\mathrm{cm} / \mathrm{det})$

Debit rembesan (q) dinyatakan dalam persamaan :

$q=k \cdot i \cdot A$

dengan :

$\mathrm{q}=$ debit rembesan $\left(\mathrm{cm}^{3} / \mathrm{det}\right)$ $\mathrm{k}=$ koefisien permeabilitas $(\mathrm{cm} / \mathrm{det})$

$\mathrm{i}=$ gradien hidrolik

A $=$ luas penampang $\left(\mathrm{cm}^{2}\right)$

Koefisien permeabilitas $(k)$ mempunyai satuan yang sama dengan kecepatan $\mathrm{cm} / \mathrm{det}$ atau $\mathrm{mm} / \mathrm{det}$. Yaitu menunjukkan ukuran tahanan tanah terhadap air, bila pengaruh sifat-sifatya dimasukkan, maka :

$k\left(\frac{c m}{d t}\right)=\frac{k \cdot \rho_{w} \cdot g}{\mu}$

dengan :

$\mathrm{k} \quad=$ koefisien absolute $\left(\mathrm{cm}^{2}\right)$, tergantung dari sifat butiran tanah

$\rho_{\mathrm{w}}=$ rapat massa air $\left(\mathrm{g} / \mathrm{cm}^{3}\right)$

$\mu \quad=$ koefisien kekentalan air $(\mathrm{g} / \mathrm{cm} . \mathrm{det})$

$\mathrm{G}=$ percepatan gravitasi $\left(\mathrm{cm} / \mathrm{det}^{2}\right)$

Geolistrik ialah suatu metode dalam geofisika yang mempelajari sifat aliran listrik di dalam bumi dan cara mendeteksinya di permukaan bumi. Pendeteksian ini meliputi pengukuran beda potensial, arus, dan elektromagnetik yang terjadi secara alamiah maupun akibat penginjeksian arus ke dalam bumi (Kanata,dan Zubaidah.,2008).

Teknik pengambilan data dalam metode geolistrik tahanan jenis terdiri dari: vertikal sounding dan lateral mapping. (Waluyo, 1984:149) :

a. Vertikal sounding

Vertikal sounding merupakan penyelidikan perubahan tahanan jenis bawah permukaan kearah vertikal. Caranya pada titik ukur yang tetap, jarak elektroda arus dan tegangan diubah atau divariasi. Konfigurasi elektroda yang biasanya dipakai adalah konfigurasi Schlumberger.

b. Lateral mapping

Lateral mapping adalah penyelidikan perubahan tahanan jenis bawah permukaan kearah lateral (horizontal). Caranya dengan jarak elektroda arus dan tegangan tetap, titik ukur dipindah atau digeser secara horizontal. Konfigurasi elektroda yang biasa dipakai adalah konfigurasi Wenner atau Dipole dipole.

Penggunaan konfigurasi Wenner Schlumberger pada metode geoelektrikal didasarkan pada kebutuhan penyelidikan perubahan tahanan jenis bawah permukaan kearah lateral (horizontal) yang biasa disebut ilustrasi lateral mapping. Terdapat beberapa keunggulan metode geoelektrikal konfigurasi Wenner Schlumberger dalam pengukuran rembesan (seepage water table) (Gumilar et al, 2014; Darsono et al, 2012): 
1. Mobilitas alat praktis dan ekonomis.

2. Tidak merusak struktur bendungan.

3. Mengefisiensi bentang jarak pengukuran yang dilakukan.

4. Memetakan kondisi bawah permukaan khususnya aliran rembesan dengan sangat baik.

5. Aplikasi metode geofisika resitivitas telah banyak digunakan seperti pencarian sumber panas bumi, survei air tanah, dan juga telah dilakukan gerakan tanah atau tanah longsor dengan Wenner Schlumberger.

6. Mudah dikerjakan.

RES2DINV adalah program komputer yang secara automatis menentukan model resistivitas 2 dimensi (2-D) untuk menentukan lapisan bawah permukaan dari hasil geoelektrikal. Model 2-D menggunakan program inversi yang terdiri dari sejumlah kotak persegi. Susunan dari kotak-kotak ini terkait oleh distribusi dari titik datum dalam pseudosection. Distribusi dan ukuran dari kotak secara otomatis dihasilkan dari program, maka jumlah kotak tidak akan melebihi jumlah datum point. Program ini dapat digunakan untuk beberapa konfigurasi yaitu konfigurasi Schlumberger, Wenner, Wenner-Schlumberger, pole-pole, dan lainlain.

Tabel 1. Harga Resistivitas Spesifik Batuan Menurut Suyono

\begin{tabular}{|l|c|}
\hline \multicolumn{1}{|c|}{ Material } & Resitivitas $(\Omega \mathbf{m})$ \\
\hline Air Pemasukan & $80-200$ \\
\hline Air Tanah & $30-100$ \\
\hline Silt - Lempung & $10-200$ \\
\hline Pasir & $100-600$ \\
\hline Pasir dan Kerikil & $100-1000$ \\
\hline Batu Lumpur & $20-200$ \\
\hline Batu Pasir & $50-500$ \\
\hline Konglomerat & $100-500$ \\
\hline Tufa & $20-200$ \\
\hline Kelompok Andesit & $100-200$ \\
\hline Kelompok Granit & $1000-10000$ \\
\hline Kelompok Chert, Slate & $200-2000$ \\
\hline
\end{tabular}

Sumber: Suyono, (1978)
Identifikasi jenis batuan pada hasil penggambaran aplikasi RES2DINV, ditentukan oleh jumlah atau nilai resistivitas batuannya. Hal ini disebabkan oleh perbedaan resistivitas setiap batuan yang dapat digunakan sebagai acuan dalam membaca keadaan bawah permukaan tanah pada timbunan tubuh bendungan. Dimana, nilai resitivitas semakin rendah akan menandakan semakin tinggi kadar air yang terkandung dalam lapisan batuan tersebut. Hal ini pula dapat digunakan sebagai dasar penentuan posisi rembesan pada tubuh bendungan. Adapun acuan yang digunakan sebagai penentu jenis batuan, yaitu seperti Tabel di atas.

\section{Uji X-Ray fluorescence spectrometry (XRF)}

XRF merupakan teknik analisis nondestruktif yang digunakan untuk identifikasi serta penentuan konsentrasi elemen yang ada pada padatan, bubuk ataupun sample cair. XRF mampu mengukur elemen dari berilium (Be) hingga Uranium pada level trace element, bahkan dibawah level ppm. Secara umum, XRF spektrometer mengukur panjang gelombang komponen material secara individu dari emisi flourosensi yang dihasilkan sampel saat diradiasi dengan sinarX (PANalytical, 2009).

Metode XRF secara luas digunakan untuk menentukan komposisi unsur suatu material. Karena metode ini cepat dan tidak merusak sampel, metode ini dipilih untuk aplikasi di lapangan dan industri untuk kontrol material. Tergantung pada penggunaannya, XRF dapat dihasilkan tidak hanya oleh sinar$\mathrm{X}$ tetapi juga sumber eksitasi primer yang lain seperti partikel alfa, proton atau sumber elektron dengan energi yang tinggi (Viklund,2008).

\section{Uji Scanning Electron Microscopy (SEM)}

SEM adalah sebuah mikroskop elektron yang didesain untuk menyelidiki permukaan dari objek solid secara langsung. SEM memiliki perbesaran $10-3000000 x$, depth of field $4-0.4 \mathrm{~mm}$ dan resolusi sebesar $1-10$ nm. Kombinasi dari perbesaran yang tinggi, depth of field yang besar, resolusi yang baik, kemampuan untuk mengetahui komposisi dan informasi kristalografi membuat SEM banyak digunakan untuk keperluan penelitian dan industri. Adapun 
fungsi utama dari SEM antara lain dapat digunakan untuk mengetahui informasiinformasi mengenai:

a. Topografi, yaitu ciri-ciri permukaan dan teksturnya (kekerasan, sifat memantulkan cahaya, dan sebagainya).

b. Morfologi, yaitu bentuk dan ukuran dari partikel penyusun objek (kekuatan, cacat pada Integrated Circuit (IC) dan chip, dan sebagainya).

c. Komposisi, yaitu data kuantitatif unsur dan senyawa yang terkandung di dalam objek (titik lebur, kereaktifan, kekerasan, dan sebagainya).

d. Informasi kristalografi, yaitu informasi mengenai bagaimana susunan dari butirbutir di dalam objek yang diamati (konduktifitas, sifat elektrik, kekuatan, dan sebagainya).

\section{BAHAN DAN METODE}

\section{Konfigurasi Wenner-Schlumberger}

Faktor geometri dari konfigurasi elektroda Wenner-Schlumberger adalah (Telford, 1990):

$\mathrm{K}_{\mathrm{w}-\mathrm{s}}=\pi \mathrm{r}(\mathrm{r}+1) \mathrm{a}$

dengan :

$\mathrm{a} \quad=$ jarak antara elektroda $\mathrm{P}_{1}$ dan $\mathrm{P}_{2}$

$r \quad=$ perbandingan jarak antara elektroda $C_{1}$ dan $\mathrm{P}_{1}$ dengan $\mathrm{P}_{2}$ dan $\mathrm{C}_{2}$

Resistivitas semu ini dirumuskan dengan: (Bisri, 1988:10)

$$
\rho_{a}=K \frac{\Delta V}{I}
$$

dengan :

$\rho_{\mathrm{a}} \quad=$ resistivitas semu (Ohm-m)

$\mathrm{K}=$ faktor geometri

$\Delta \mathrm{V}=$ beda potensial (Volt)

$\mathrm{I}=$ kuat arus (Ampere)

Nilai perbandingan antara beda potensial dan besarnya arus yang diinjeksikan $(\Delta V / I)$ atau sama dengan nilai resistivitas hasil pendugaan $(\mathrm{R})$, maka untuk rumus di atas berubah menjadi:

$\rho_{a}=K \times R$

dengan:

$\mathrm{R}$ =besarnya resistivitas hasil pendugaan (Ohm)

Oleh karena itu resistivitas yang diperoleh dari persamaan tersebut bukan merupakan resistivitas yang sebenarnya, melainkan resistivitas semu atau apparent resistivity $\left(\rho_{\mathrm{a}}\right)$.

\section{Lokasi Studi}

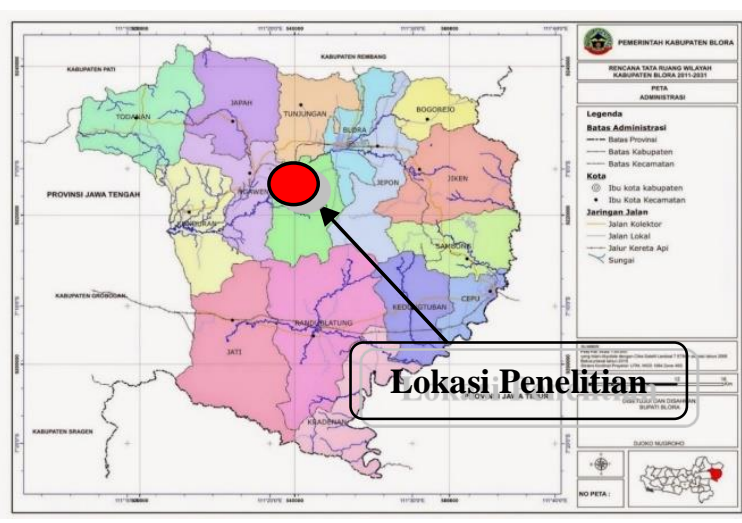

Gambar 1 Peta Lokasi Studi

(Sumber : Pemerintah Kabupaten Blora, 2011)

\section{Pengumpulan Data}

Data yang digunakan dalam studi ini antara lain :

1. Data teknik eksisting Waduk Greneng

2. Data teknis pekerjaan inspeksi Waduk Greneng

\section{Pengolahan Data}

Adapun langkah-langkah pengerjaan studi, sebagai berikut:

1. Pengumpulan data berupa data lokasi daerah yang akan diukur melalui Google Earth tahun 2017.

2. Perencanaan pengukuran, berdasarkan panjang garis kemudian dapat direncanakan kombinasi perletakan elektroda C1, C2, P1 dan P2.

3. Survey pendahuluan di lapangan dilakukan untuk melihat potensi rembesan visual.

4. Pengukuran geolistrik menggunakan konfigurasi Wenner Schlumberger dilakukan setelah proses perencanaan telah menghasilkan hasil yang dibutuhkan berupa, posisi, jarak, spasi.

5. Perhitungan hasil pengukuran di lapangan menghasilkan data berupa arus (I) serta tegangan ( $V$ ) yang diperoleh melalui pembacaan alat geolistrik.

6. Pengolahan software RES2DINV, hasil pengolahan ini berupa gambar melintang dengan kombinasi warna yang mewakili jenis-jenis batuan.

7. Pembacaan jenis batuan dilakukan analisis batuan dengan mengacu pada 
tabel resistivitas semu batuan menurut Telford.

8. Analisis rembesan yang terdapat pada potongan melintang hasil pengggambaran aplikasi RES2DINV. Penentuan posisi rembesan dilakukan dengan memperhatikan nilai resistivitas dari batuan.

\section{HASIL DAN PEMBAHASAN \\ Data Pengukuran di Lapangan}

Berdasarkan pengukuran di lapangan, data yang diperoleh berupa nilai tahanan jenis (R) lapisan geologi bawah permukaan yang berbeda-beda berdasarkan spasi elektroda yang digunakan pada saat pendugaan.

Pengukuran alat geolistrik dengan menggunakan konfigurasi WennerSchlumberger dilakukan dengan bentang garis kerja (line) 1 sepanjang $100 \mathrm{~m}$. Pelaksanaan pendugaan dilakukan dengan menggunakan jarak masing-masing elektroda yang telah ditentukan sebelumnya. Berdasarkan pengamatan di lapangan diperoleh data-data hasil pengukuran alat geolistrik tiap garis kerja.

\section{Perhitungan Tahanan Jenis Semu}

Perhitungan untuk nilai tahanan jenis semu atau resistivitas semu dari model konfigurasi Wenner-Schlumberger pada pembacaan pengukuran 1 garis kerja (line) 1 ialah sebagai berikut :

$\begin{array}{ll}\text { Spasi elektroda } & =5 \text { meter } \\ \text { Tegangan Arus } & =240,1 \mathrm{mV} \\ \text { Kuat Arus (I) } & =537 \mathrm{~mA}\end{array}$

Resistivitas pendugaan $(\mathrm{R})=\Delta V / I$

$$
\begin{aligned}
& =240,1 / 537 \\
& =0,4471 \mathrm{Ohm} \\
& =\pi r(r+1) a \\
& =3,14 \times 1(1+1) 5 \\
& =12,56 \mathrm{~m} \\
\text { Nilai Resistivitas Semu } & =\mathrm{K} \times \mathrm{R} \\
& =12,56 \times 0,44 \\
& =5,6158 \mathrm{Ohm} . \mathrm{m}
\end{aligned}
$$

\section{Analisa Rembesan pada Aplikasi RES2DINV}

Pengukuran lapangan dilakukan dengan memilih beberapa garis kerja atau disebut dengan Line berdasarkan keadaan lapangan.

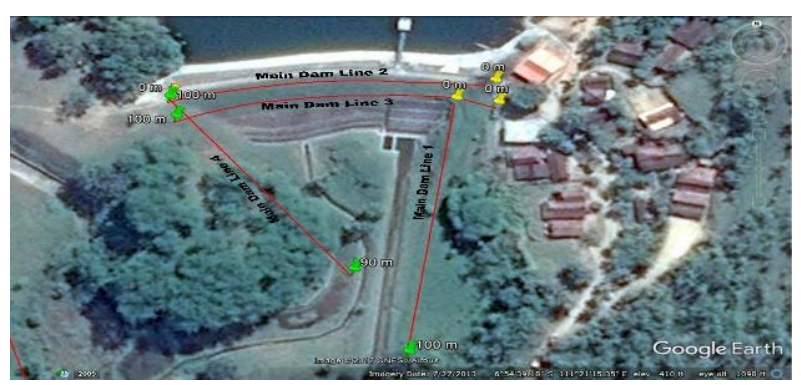

Gambar 2. Sketsa garis kerja di lapangan

Sumber: Google Earth, 2017

Pengukuran lapangan dilakukan dengan memilih beberapa garis kerja atau disebut dengan Line berdasarkan keadaan lapangan. Adapun dalam pengukuran ini dipilih 4 (empat) Line yang terdapat pada areal bangunan bendungan utama atau Main Dam. Jumlah garis kerja ini dianggap telah mewakili daerah yang memiliki potensi terhadap aliran rembesan pada tubuh bendungan yang sebelumnya diperoleh melalui survey pendahuluan. Panjang tiap garis sebesar 100 meter sedangkan pada Line 4 menggunakan 90 meter. Pemilihan panjang Line disesuaikan dengan kebutuhan serta telah mewakili keseluruhan daerah lapangan sedangkan, pada Line 4 terdapat lahan persawahan sehingga hanya menggunakan panjang 90 meter. Jarak tiap elektroda menggunakan 10 meter sesuai dengan jumlah peralatan geolistrik yang dimiliki.

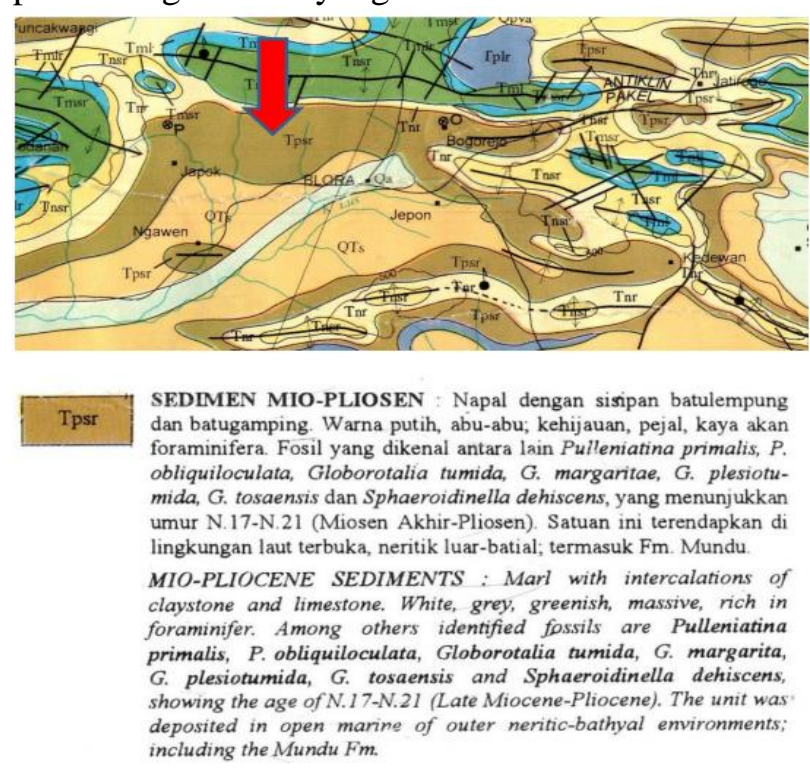

Gambar 3. Formasi geologi daerah Blora

Sumber : Peta Geologi Lembar Kabupaten Blora, 1993

Peta geologi daerah Blora menunjukkan bahwa formasi batuan pada daerah Waduk 
Greneng berupa napal. Berdasarkan peta ini, dapat disimpulkan bahwa material penyusun timbunan tubuh Waduk Greneng berupa napal pula. Penentuan awal ini dianggap efektif, sebab kurang tersedianya data teknis pembangunan/konstruksi tubuh bendungan ini. Hal ini disebabkan oleh umur bendungan yang mencapai 100 tahun.

Berdasarkan hasil pengolahan data aplikasi RES2DINV diperoleh hasil pola-pola warna batuan di bawah permukaan garis kerja. Dalam hal ini, nilai resistivitas menunjukkan jenis tiap batuan yang ada. Pola rembesan ditunjukkan oleh warna biru yang mewakili nilai resistivitas rendah. Dimana, secara teoritis, nilai resistivitas semakin rendah menunjukkan semakin basahnya suatu batuan. Dengan demikian diperoleh hasil analisis posisi rembesan sebagai berikut :

\section{a. Line 1}

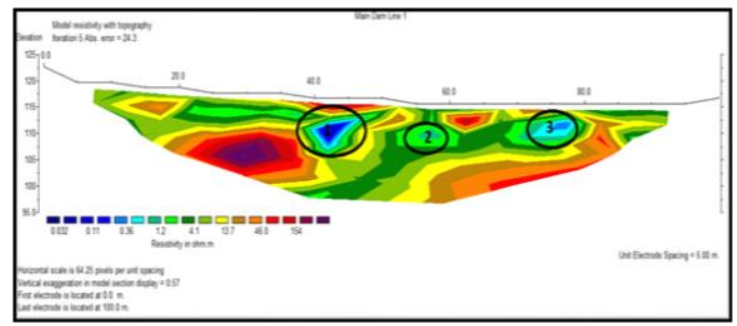

Gambar 4. Hasil analisa posisi rembesan Line 1

Sumber : Hasil Pengolahan Aplikasi RES2DINV, 2017

Tabel 2. Analisis Posisi Rembesan Line 1

\begin{tabular}{|c|c|}
\hline Lokasi & Keterangan \\
\hline 1 & $\begin{array}{l}\text { Terdapat potensi rembesan pada } \\
\text { elevasi } 105-115 \text {, serta pada } \\
\text { jarak garis kerja } 40-50 \text { m. } \\
\text { Jenis batuan pada spot ini ialah } \\
\text { napal basah dengan resitivitas } \\
0,11-0,036 \text { Ohm.m. Letak } \\
\text { garis kerja } 1 \text { terletak pada sisi } \\
\text { kanan waduk, dimana diduga } \\
\text { aliran air berasal dari aliran air } \\
\text { tanah. }\end{array}$ \\
\hline 2 & $\begin{array}{l}\text { Terdapat potensi rembesan pada } \\
\text { elevasi } 110-115 \text {, serta pada } \\
\text { jarak garis kerja } 55-60 \mathrm{~m} \text {. } \\
\text { Jenis batuan pada spot ini ialah } \\
\text { napal basah dengan resitivitas } \\
\text { sekitar } 1,2 \text { Ohm. Namun dengan } \\
\text { warna yang ditunjukan, dapat } \\
\text { diketahui bahwa spot ini lebih } \\
\text { kering dari spot } 1 \text {. Pendugaan } \\
\text { sumber rembesan relatif sama }\end{array}$ \\
\hline
\end{tabular}

\begin{tabular}{|c|l|}
\hline Lokasi & \multicolumn{2}{|c|}{ Keterangan } \\
\hline & dengan spot 1. \\
\hline \multirow{3}{*}{3} & Posisi potensi rembesan pada \\
elevasi $110-115$, serta pada \\
jarak garis kerja $70-80 \mathrm{~m}$. \\
Jenis batuan pada spot ini ialah \\
napal basah dengan nilai \\
resitivitas rendah sekitar 0,11 - \\
0,036 Ohm.m. Pendugaan \\
sumber rembesan relatif sama \\
dengan spot 1.
\end{tabular}

Sumber : Hasil Pengolahan Aplikasi RES2DINV, 2017

b. Line 2

Tabel 3. Analisis Posisi Rembesan Line 2

\begin{tabular}{|c|c|}
\hline Lokasi & Keterangan \\
\hline 1 & $\begin{array}{l}\text { Terdapat potensi rembesan pada } \\
\text { elevasi } 118-122 \text {, serta pada } \\
\text { jarak garis kerja } 5-25 \mathrm{~m} \text {. Jenis } \\
\text { batuan pada spot ini ialah napal } \\
\text { basah dengan resitivitas } 1,2- \\
3,0 \text { Ohm.m. Letak garis kerja } 2 \\
\text { terletak pada tubuh bendungan, } \\
\text { dimana diduga aliran air berasal } \\
\text { dari aliran air waduk. }\end{array}$ \\
\hline 2 & $\begin{array}{l}\text { Terdapat potensi rembesan pada } \\
\text { elevasi } 114-122 \text {, serta pada } \\
\text { jarak garis kerja } 30-40 \mathrm{~m} \text {. Jenis } \\
\text { batuan pada spot ini ialah napal } \\
\text { basah dengan resitivitas sekitar } \\
1,2-3,0 \text { Ohm.m. Pendugaan } \\
\text { sumber rembesan relatif sama } \\
\text { dengan spot } 1 \text {. }\end{array}$ \\
\hline 3 & $\begin{array}{l}\text { Posisi potensi rembesan pada } \\
\text { elevasi } 110-115 \text {, serta pada } \\
\text { jarak garis kerja } 40-50 \mathrm{~m} \text {. Jenis } \\
\text { batuan pada spot ini ialah napal } \\
\text { basah dengan nilai resitivitas } \\
\text { rendah sekitar } 0,44-3,0 \\
\text { Ohm.m. Pendugaan sumber } \\
\text { rembesan berupa air waduk. }\end{array}$ \\
\hline 4 & $\begin{array}{l}\text { Posisi potensi rembesan pada } \\
\text { elevasi } 102-118 \text {, serta pada } \\
\text { jarak garis kerja } 30-65 \mathrm{~m} \text {. Jenis } \\
\text { batuan pada spot ini ialah napal } \\
\text { basah dengan nilai resitivitas } \\
\text { rendah sekitar } 0,17-3,0 \\
\text { Ohm.m. Luasan daerah dengan } \\
\text { resitivitas rendah pada spot ini } \\
\text { sangat luas disbanding lainnya. } \\
\text { Pendugaan sumber rembesan } \\
\text { berupa air waduk. }\end{array}$ \\
\hline 5 & $\begin{array}{l}\text { Terdapat potensi rembesan pada } \\
\text { elevasi } 110-122 \text {, serta pada }\end{array}$ \\
\hline
\end{tabular}




\begin{tabular}{|l|l|}
\hline Lokasi & \multicolumn{1}{|c|}{ Keterangan } \\
\hline & jarak garis kerja $70-80 \mathrm{~m}$. Jenis \\
batuan pada spot ini ialah napal \\
basah dengan resitivitas 1,2 - \\
3,0 Ohm.m. Letak garis kerja 2 \\
terletak pada tubuh bendungan, \\
dimana diduga aliran air berasal \\
dari aliran air waduk.
\end{tabular}

Sumber : Hasil Pengolahan Aplikasi RES2DINV, 2017

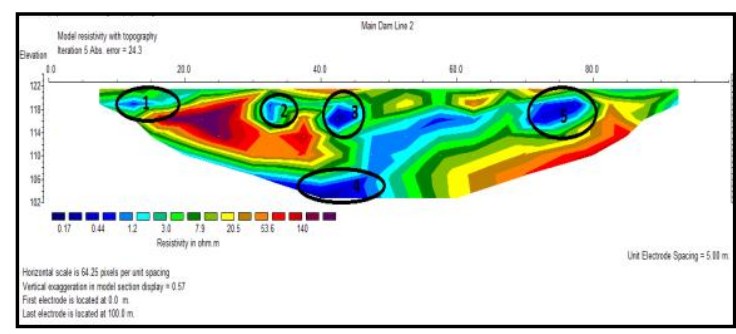

Gambar 5. Hasil analisa posisi rembesan Line 2

Sumber : Hasil Pengolahan Aplikasi RES2DINV, 2017

\section{c. Line 3}

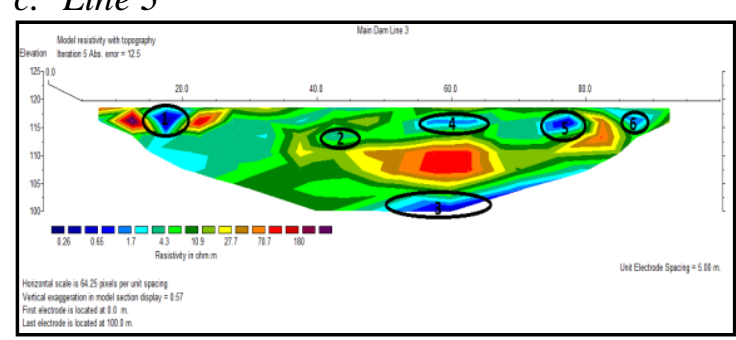

Gambar 6. Hasil analisa posisi rembesan Line 3

Sumber : Hasil Pengolahan Aplikasi RES2DINV, 2017

\section{d. Line 4}

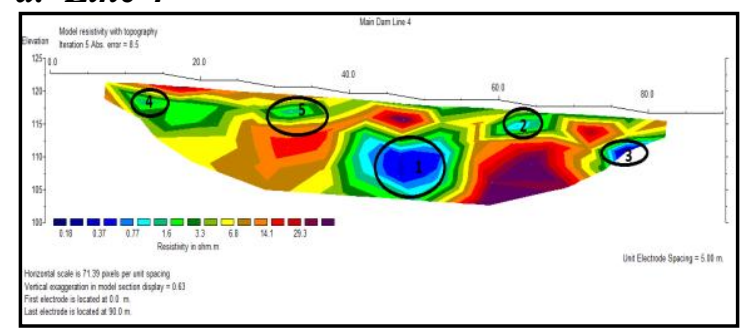

Gambar 7. Hasil analisa posisi rembesan Line 4

Sumber : Hasil Pengolahan Aplikasi RES2DINV, 2017

Identifikasi jenis batuan pada hasil penggambaran aplikasi RES2DINV, ditentukan oleh jumlah atau nilai resitivitas batuannya. Hal ini disebabkan oleh perbedaan resitivitas setiap batuan yang dapat digunakan sebagai acuan dalam membaca keadaan bawah permukaan tanah pada timbunan tubuh bendungan. Dimana, nilai resitivitas semakin rendah akan menandakan semakin tinggi kadar air yang terkandung dalam lapisan batuan tersebut. Hal ini pula dapat digunakan sebagai dasaran penentuan posisi rembesan pada tubuh bendungan.

Tabel 4. Analisis Posisi Rembesan Line 3

\begin{tabular}{|c|c|}
\hline Lokasi & Keterangan \\
\hline 1 & $\begin{array}{l}\text { Terdapat potensi rembesan pada } \\
\text { elevasi } 105-120 \text {, pada jarak } \\
\text { garis kerja } 15-40 \mathrm{~m} \text {. Jenis } \\
\text { batuan pada spot ini napal basah } \\
\text { dengan resitivitas } 0,65-4,3 \\
\text { Ohm.m. Spot pada jarak } 15-20 \\
\text { m elevasi } 115-120 \text { cenderung } \\
\text { lebih basah daripada bagian spot } \\
\text { lainnya, terlihat dari warna } \\
\text { resivitas yang diwakili. Letak } \\
\text { garis kerja } 3 \text { terletak pada tubuh } \\
\text { bendungan, dimana diduga aliran } \\
\text { air berasal dari aliran air waduk. }\end{array}$ \\
\hline 2 & $\begin{array}{l}\text { Terdapat potensi rembesan pada } \\
\text { elevasi } 112,5-117,5 \text { pada jarak } \\
\text { garis kerja } 40-45 \mathrm{~m} \text {. Jenis } \\
\text { batuan pada spot ini napal basah } \\
\text { dengan resitivitas sekitar } 4,3 \\
\text { Ohm.m, sehingga lebih kering } \\
\text { daripada spot } 1 . \text { Pendugaan } \\
\text { sumber rembesan sama dengan } \\
\text { spot } 1 .\end{array}$ \\
\hline 3 & $\begin{array}{l}\text { Posisi potensi rembesan pada } \\
\text { elevasi } 100-110 \text {, serta pada jarak } \\
\text { garis kerja } 50-80 \mathrm{~m} \text {. Jenis } \\
\text { batuan pada spot ini napal basah } \\
\text { dengan nilai resitivitas rendah } \\
\text { sekitar } 0,65-4,3 \text { Ohm.m. } \\
\text { Pendugaan sumber rembesan } \\
\text { berupa air waduk. }\end{array}$ \\
\hline 4 & $\begin{array}{l}\text { Posisi potensi rembesan pada } \\
\text { elevasi } 115-120 \text {, serta pada jarak } \\
\text { garis kerja } 55-65 \mathrm{~m} \text {. Jenis } \\
\text { batuan pada spot ini napal basah } \\
\text { dengan nilai resitivitas rendah } \\
\text { sekitar } 1,7-4,3 \text { Ohm.m. } \\
\begin{array}{l}\text { Pendugaan sumber rembesan } \\
\text { berupa air waduk. }\end{array}\end{array}$ \\
\hline 5 & $\begin{array}{l}\text { Terdapat potensi rembesan pada } \\
\text { elevasi } 110-120 \text {, serta pada jarak } \\
\text { garis kerja } 70-80 \mathrm{~m} \text {. Jenis } \\
\text { batuan pada spot ini napal basah } \\
\text { dengan resitivitas } 0,65-4,3 \\
\text { Ohm.m. Letak garis kerja } 3\end{array}$ \\
\hline
\end{tabular}




\begin{tabular}{|c|l|}
\hline Lokasi & \multicolumn{1}{|c|}{ Keterangan } \\
\hline & $\begin{array}{l}\text { terletak pada tubuh bendungan, } \\
\text { dimana diduga aliran air berasal } \\
\text { dari aliran air waduk. }\end{array}$ \\
\hline \multirow{6}{6}{6} & $\begin{array}{l}\text { Posisi potensi rembesan pada } \\
\text { elevasi } 115-120 \text {, serta pada jarak } \\
\text { garis kerja } 80-90 \text { m. Jenis } \\
\text { batuan pada spot ini napal basah } \\
\text { dengan nilai resitivitas rendah } \\
\text { sekitar 1,7 }-4,3 \text { Ohm.m. } \\
\text { Pendugaan sumber rembesan } \\
\text { berupa air waduk. }\end{array}$ \\
\hline
\end{tabular}

Sumber : Hasil Pengolahan Aplikasi

RES2DINV, 2017

Tabel 5. Analisis Posisi Rembesan Line 4

\begin{tabular}{|c|c|}
\hline Lokasi & Keterangan \\
\hline 1 & $\begin{array}{l}\text { Terdapat potensi rembesan pada } \\
\text { elevasi } 105-115 \text {, serta pada jarak } \\
\text { garis kerja } 40-55 \text { m. Jenis batuan } \\
\text { pada spot ini ialah napal basah } \\
\text { dengan resitivitas } 0,37-0,77 \\
\text { Ohm.m. Letak garis kerja } 4 \\
\text { terletak pada tubuh bendungan, } \\
\text { dimana diduga aliran air berasal } \\
\text { dari aliran air waduk. }\end{array}$ \\
\hline 2 & $\begin{array}{l}\text { Terdapat potensi rembesan pada } \\
\text { elevasi } 114-122 \text {, serta pada jarak } \\
\text { garis kerja } 60-65 \text { m. Jenis batuan } \\
\text { pada spot ini ialah napal basah } \\
\text { dengan resitivitas sekitar } 0,77 \\
\text { Ohm.m. Pendugaan sumber } \\
\text { rembesan relatif sama dengan spot } \\
1 .\end{array}$ \\
\hline 3 & $\begin{array}{l}\text { Posisi potensi rembesan pada } \\
\text { elevasi } 105-115 \text {, serta pada jarak } \\
\text { garis kerja } 75-80 \text { m. Jenis batuan } \\
\text { pada spot ini ialah napal basah } \\
\text { dengan nilai resitivitas rendah } \\
\text { sekitar } 0,37-0,77 \text { Ohm.m. } \\
\text { Pendugaan sumber rembesan } \\
\text { berupa air waduk. }\end{array}$ \\
\hline 4 & $\begin{array}{l}\text { Posisi potensi rembesan pada } \\
\text { elevasi } 115-120 \text {, serta pada jarak } \\
\text { garis kerja } 10-15 \mathrm{~m} \text {. Jenis batuan } \\
\text { pada spot ini ialah napal basah } \\
\text { dengan nilai resitivitas rendah } \\
\text { sekitar } 1,6 \text { Ohm.m. Spot ini } \\
\text { memiliki resitivitas paling tinggi } \\
\text { dibanding spot rembesan lainnya, } \\
\text { sehingga spot ini lebih kering. } \\
\text { Pendugaan sumber rembesan } \\
\text { berupa air waduk. }\end{array}$ \\
\hline 5 & $\begin{array}{l}\text { Posisi potensi rembesan pada } \\
\text { elevasi } 115-120, \text { serta pada jarak }\end{array}$ \\
\hline
\end{tabular}

\begin{tabular}{|l|l|}
\hline Lokasi & \multicolumn{1}{|c|}{ Keterangan } \\
\hline & garis kerja $30-35 \mathrm{~m}$. Jenis batuan \\
pada spot ini ialah napal basah \\
dengan nilai resitivitas rendah \\
sekitar 1,6 Ohm.m. Spot ini \\
memiliki resitivitas paling tinggi \\
dibanding spot rembesan lainnya, \\
sehingga spot ini lebih kering. \\
Pendugaan sumber rembesan \\
berupa air waduk. \\
\hline
\end{tabular}

Sumber: Hasil Pengolahan Aplikasi

RES2DINV, 2017

\section{Hasil Pengujian XRF}

Pengujian XRF (X-Ray Fluorecence) dalam kegiatan ini menggunakan tiga sampel tanah hasil pengeboran pada tubuh Bendungan Greneng. Pengujian dilakukan pada tiga sampel tanah yang dianggap telah mewakili keseluruhan material tubuh bendungan. Hasil pengujian tiga sampel ini dianggap mewakili keseluruhan timbunan pada tubuh bendungan sebab, bendungan ini merupakan bendungan tipe homogen. Adapun hasil uji XRF yang dilakukan di Laboratorium Sentral Mineral dan Material Maju FMIPA, Universitas Negeri Malang yaitu sebagai berikut :

Tabel 6. Hasil Pengujian XRF Material Uji BHG 2.9

a. No Filter

\begin{tabular}{|c|c|}
\hline Unsur Penyusun & Persentase Jumlah \\
\hline $\mathrm{Al}$ & 5,9 \\
\hline $\mathrm{Si}$ & 26,4 \\
\hline $\mathrm{K}$ & 1,5 \\
\hline $\mathrm{Ca}$ & 44,7 \\
\hline $\mathrm{Ti}$ & 1,62 \\
\hline $\mathrm{V}$ & 0,02 \\
\hline $\mathrm{Cr}$ & 0,086 \\
\hline $\mathrm{Mn}$ & 0,22 \\
\hline $\mathrm{Fe}$ & 17,5 \\
\hline $\mathrm{Cu}$ & 0.092 \\
\hline $\mathrm{Sr}$ & 0,46 \\
\hline $\mathrm{In}$ & 1,3 \\
\hline $\mathrm{Eu}$ & 0,3 \\
\hline
\end{tabular}

Sumber: Hasil Uji XRF, 2017

b. Helium

\begin{tabular}{|c|c|}
\hline Unsur Penyusun & Persentase Jumlah \\
\hline $\mathrm{Al}$ & 5,15 \\
\hline $\mathrm{Si}$ & 28,1 \\
\hline $\mathrm{P}$ & 0,37 \\
\hline $\mathrm{K}$ & 5,31 \\
\hline $\mathrm{Ca}$ & 30,7 \\
\hline
\end{tabular}




\begin{tabular}{|c|c|}
\hline Unsur Penyusun & Persentase Jumlah \\
\hline $\mathrm{Ti}$ & 4,8 \\
\hline $\mathrm{V}$ & 0,59 \\
\hline $\mathrm{Cr}$ & 2,0 \\
\hline $\mathrm{Ge}$ & 1,5 \\
\hline $\mathrm{Ba}$ & 4,5 \\
\hline $\mathrm{Nd}$ & 17 \\
\hline
\end{tabular}

Sumber: Hasil Uji XRF, 2017

Dari hasil XRF menunjukkan kandungan material uji BHG 2.9 untuk unsur $\mathrm{Ca}$ pada sampel no filter cukup tinggi 44,7 sedangkan sampel helium Ca 30,7\%. Untuk material uji BHG 2.14 unsur penyusun Si pada sampel no filter cukup tinggi $41,5 \%$, sedangkan pada sampel helium unsur penyusun $\mathrm{Ca}$ (calcium) $30,7 \%$. Untuk material uji BHG 2.10 untuk unsur penyusun $\mathrm{Ca}$ pada sampel no filter cukup tinggi $53,1 \%$, sedangkan pada sampel helium unsur penyusun $\mathrm{Ca}$ sangat tinggi $71,7 \%$.

Tabel 7. Hasil Pengujian XRF Material Uji

$$
\text { BHG } 2.14
$$

a. No Filter

\begin{tabular}{|c|c|}
\hline Unsur Penyusun & Persentase Jumlah \\
\hline $\mathrm{Al}$ & 10 \\
\hline $\mathrm{Si}$ & 41,5 \\
\hline $\mathrm{K}$ & 3,75 \\
\hline $\mathrm{Ca}$ & 18,2 \\
\hline $\mathrm{Ti}$ & 2,40 \\
\hline $\mathrm{V}$ & 0,05 \\
\hline $\mathrm{Cr}$ & 0,096 \\
\hline $\mathrm{Mn}$ & 0,13 \\
\hline $\mathrm{Fe}$ & 21,7 \\
\hline $\mathrm{Cu}$ & 0.12 \\
\hline $\mathrm{Zn}$ & 0,02 \\
\hline $\mathrm{Sr}$ & 0,79 \\
\hline $\mathrm{Zr}$ & 0,9 \\
\hline $\mathrm{Re}$ & 0,3 \\
\hline
\end{tabular}

Sumber: Hasil Uji XRF, 2017

\section{b. Helium}

\begin{tabular}{|c|c|}
\hline Unsur Penyusun & Persentase Jumlah \\
\hline $\mathrm{Al}$ & 5,15 \\
\hline $\mathrm{Si}$ & 28,1 \\
\hline $\mathrm{P}$ & 0,37 \\
\hline $\mathrm{K}$ & 5,31 \\
\hline $\mathrm{Ca}$ & 30,7 \\
\hline $\mathrm{Ti}$ & 4,8 \\
\hline $\mathrm{V}$ & 0,59 \\
\hline $\mathrm{Cr}$ & 2,0 \\
\hline $\mathrm{Ge}$ & 1,5 \\
\hline $\mathrm{Ba}$ & 4,5 \\
\hline $\mathrm{Nd}$ & 17 \\
\hline
\end{tabular}

Sumber: Hasil Uji XRF, 2017
Tabel 8. Hasil Pengujian XRF Material Uji BHG 3.10

\section{a. No Filter}

\begin{tabular}{|c|c|}
\hline Unsur Penyusun & Persentase Jumlah \\
\hline $\mathrm{Si}$ & 20,9 \\
\hline $\mathrm{K}$ & 1,7 \\
\hline $\mathrm{Ca}$ & 53,1 \\
\hline $\mathrm{Ti}$ & 1,46 \\
\hline $\mathrm{V}$ & 0,02 \\
\hline $\mathrm{Cr}$ & 0,081 \\
\hline $\mathrm{Mn}$ & 0,26 \\
\hline $\mathrm{Fe}$ & 16,1 \\
\hline $\mathrm{Cu}$ & 0,083 \\
\hline $\mathrm{Sr}$ & 2,0 \\
\hline $\mathrm{Zr}$ & 0,4 \\
\hline $\mathrm{Mo}$ & 2,3 \\
\hline $\mathrm{In}$ & 1,4 \\
\hline $\mathrm{Eu}$ & 0,3 \\
\hline
\end{tabular}

Sumber: Hasil Uji XRF, 2017

\section{b. Helium}

\begin{tabular}{|c|c|}
\hline Unsur Penyusun & Persentase Jumlah \\
\hline $\mathrm{Al}$ & 1,3 \\
\hline $\mathrm{Si}$ & 9,87 \\
\hline $\mathrm{S}$ & 0,57 \\
\hline $\mathrm{K}$ & 1,6 \\
\hline $\mathrm{Ca}$ & 71,7 \\
\hline $\mathrm{Ti}$ & 2,1 \\
\hline $\mathrm{V}$ & 0,2 \\
\hline $\mathrm{Cr}$ & 1,1 \\
\hline $\mathrm{Mn}$ & 6,5 \\
\hline $\mathrm{In}$ & 1,6 \\
\hline $\mathrm{Ba}$ & 3,4 \\
\hline
\end{tabular}

Sumber: Hasil Uji XRF, 2017

\section{Hasil Pengujian SEM}

Pengujian SEM (Scanning Electron Microscopy) juga menggunakan tiga sampel tanah hasil sampel pengeboran pada tubuh Bendungan Greneng sama dengan pengujian XRF sebelumnya. Hasil pengujian tiga sampel ini dianggap mewakili keseluruhan timbunan pada tubuh bendungan yang merupakan tipe homogen. Adapun hasil uji SEM yang dilakukan di Laboratorium Sentral Mineral dan Material Maju FMIPA, Universitas Negeri Malang yaitu sebagai berikut : 
1. Sampel BHG 2.9

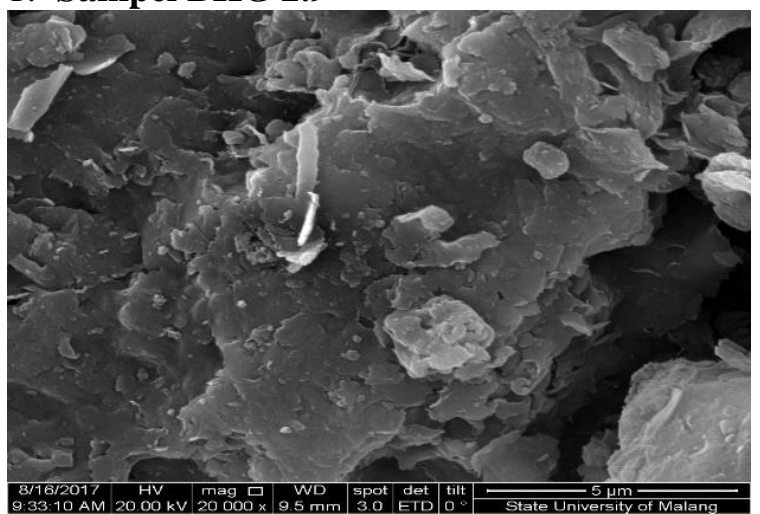

Gambar 8. Gambar Uji SEM Perbesaran 5000x BHG 2.9

Sumber : Hasil Uji SEM 2017

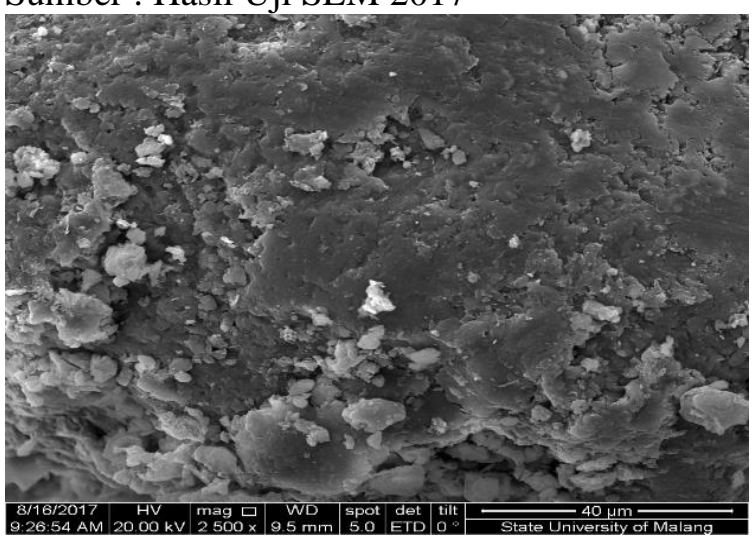

Gambar 9. Gambar Uji SEM Perbesaran 50000x BHG 2.9

Sumber : Hasil Uji SEM 2017

\section{Sampel BHG 2.14}

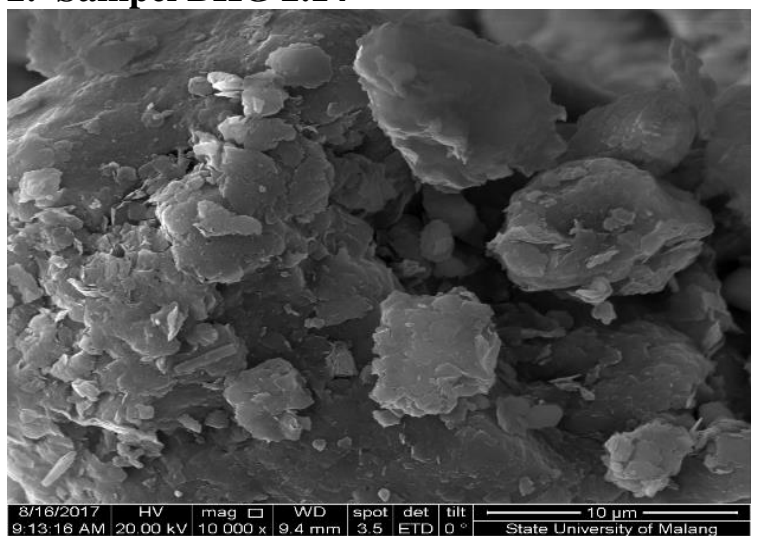

Gambar 10. Gambar Uji SEM Perbesaran 5000x BHG 2.14

Sumber : Hasil Uji SEM 2017

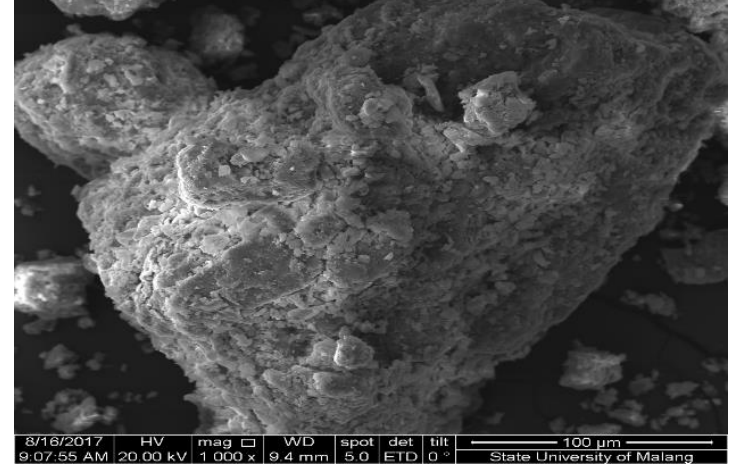

Gambar 11. Gambar Uji SEM Perbesaran 50000x BHG 2.14

Sumber : Hasil Uji SEM 2017

\section{Sampel BHG 3.10}

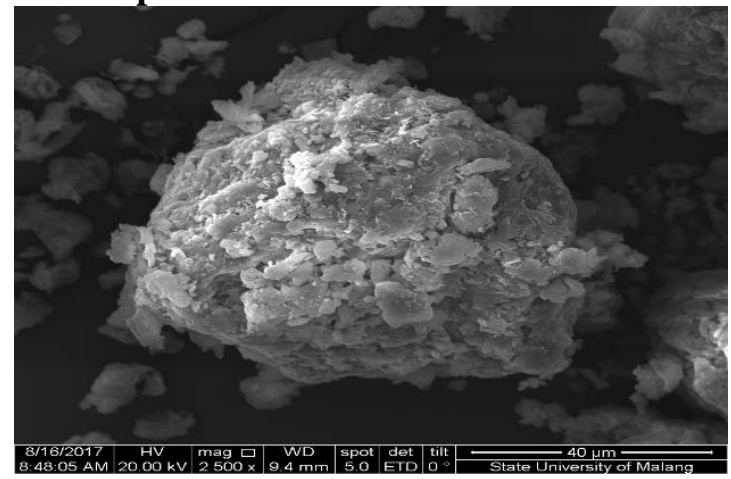

Gambar 12. Gambar Uji SEM Perbesaran 5000x BHG 3.10

Sumber : Hasil Uji SEM 2017

Dari hasil uji SEM (Scan Elektron Microscope) dilakukan perbesaran objek 5000x dan 50000x serta resolusi yang jauh lebih baik daripada mikroskop cahaya. Dikarenakan mikroskop eletron menggunakan jauh lebih banyak energi dan radiasi elektromagnetik yang lebih pendek dibandingkan mikroskop cahaya. Sehingga hasil SEM mampu mengetahui komposisi dan informasi kristalografi dari sampel BHG 2.9; BHG 2.14 dan BHG 2.10.

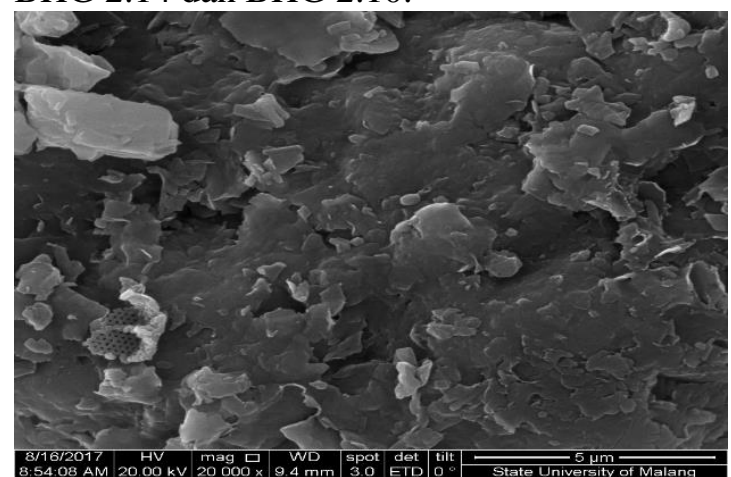

Gambar 13. Gambar Uji SEM Perbesaran 20000x BHG 3.10

Sumber : Hasil Uji SEM 2017 


\section{KESIMPULAN}

1. Berdasarkan hasil survey pendahuluan pada spot-spot rembesan pada tubuh bendungan yang terjadi di hilir Main Dam Waduk Geneng secara visual mengenai keadaan rembesan yang ada.. Terdapat 6 (enam) spot rembesan dimana, satu spot rembesan diduga sebagai akibat aliran air tanah. Adapun indikasi posisi rembesan tersebut keseluruhannya terletak pada hilir tubuh bendungan, Waduk Greneng.

2. Hasil pengukuran alat Geolistrik konfigurasi Wenner-Schlumberger dengan pengolahan aplikasi RES2DINV diperoleh hasil posisi rembesan yang diwakili oleh nilai resitifitas paling rendah dengan gradasi berwarna biru. Hasil keempat garis kerja dapat diperhatikan pada Gambar 3 sampai Gambar 6, setiap Line menunjukan adanya potensi rembesan yang berbedabeda namun, dapat diketahui terdapat potensi aliran rembesan pada setiap daerah Main Dam Waduk Greneng yang ditandai dengan adanya resitivitas rendah yang ditandai dengan warna biru.

\section{DAFTAR PUSTAKA}

Bisri, Muhammad, 1988. Aliran Air Tanah. Malang: Himpunan Mahasiswa Pengairan.

Darsono et al. (2012).Identifikasi Bidang Gelincir Pemicu Bencana Tanah Longsor Dengan Metode Resitivitas 2 Dimensi di Desa Pablengan Kecamatan Matesih Kabupaten Karanganyar.Surakarta:Indonesian Journal Physics
Gumilar et al. (2014).Metode Resitivitas Konfigurasi Wenner untuk Menganalisis Aliran Rembesan (Seepage) di Bendung Alam Wae Ela, Ambon. Universitas Pendidikan Indonesia

Hardiyatmo, H.C. (2007). Mekanika Tanah II, Edisi Keempat. Gadjah Mada University Press, Yogyakarta.

Kanata, Bulkis dan Zubaidah. (2008). Pemodelan Fisika Aplikasi Metode Geolistrik Konfigurasi Schlumberger untuk Investigasi Keberadaan Air Tanah. Jurnal Vol. 7 No. 1 Januari - Juni 2008. Mataram.

Laboratorium Tanah dan Air Tanah. (2016). Buku Panduan Praktikum Pengelolaan Air Tanah.Malang:Teknik Pengairan Fakultas Teknik Universitas Brawijaya

PANalytical B.V. (2009). X-ray Fluorescence Spectrometry.http://www.panalytical.co $\mathrm{m} /$ index.cfm?pid=130, Diakses pada tanggal 19 Oktober 2017, pukul: 20.00 WIB.

Sosrodarsono, Suyono dan Kensaku Takeda. (1981). Bendungan Type Urugan. Jakarta : PT. Pradnya Paramita

Telford, W.M., Geldart, L.P. dan Sheriff, R.E. (1998). Applied Geophysic. Second Edition. Cambridge University Press: New York.

Viklund, A. (2008). Teknik Pemeriksaan Material Menggunakan XRF, XRD dan SEM-EDS,

(Online). Tersedia:http://labinfo.wordpre ss.com/. Diakses pada tanggal 19 Oktober 2017, pukul: 20.30 WIB.

Waluyo, 1984. Metode Resistivitas. Yogyakarta: Universitas Gadjah Mada. 